\title{
Usefulness of Collegiate Aviation Publications: What Aviation Educators Say
}

\author{
Randy Johnson, Ray Hamilton, Brian Gibson and Joe Hanna \\ Auburn University
}

\begin{abstract}
Evaluations of refereed research journals typically target their quality. Because of the hybrid nature of aviation education as a discipline and its orientation toward applied research, this research expands the scope of the evaluation process to encompass professional publications that address practitioner interests and focuses on three educational areas: 1) quality, 2) contribution to the discipline, and 3) relevance to ongoing research. Thirty-one out of 205 aviation educators queried responded to the survey by selecting and assessing periodicals pertinent to the discipline. One trade journal, Aviation Week and Space Technology, and four peer-refereed journals, the Collegiate Aviation Review, the Journal of Air Transportation, International Journal of Applied Aviation Studies, and the Journal of Aviation and Aerospace Education and Research achieved the highest composite scores based on analysis of the survey responses.
\end{abstract}

\section{BACKGROUND}

The milestone marking aviation education's entrance into academia was the Civilian Pilot Training Act of 1939. Civilian Aeronautics Authority's (CAA) Robert H. Hinkley's goal was the "air-conditioning" of the United States-that of "imprinting young Americans with the wonder of flight, its unlimited potential" and "shaping the thinking of young people in 'aeronautical terms'” (Johnson, 2005, p. 8; Preston, 1998; Wilson, 1979). While aviation education programs could be found at such campuses as Auburn University and Parks College prior to 1939, the Civilian Pilot Training Program (CPTP) (later renamed the War Training Service (WTS)) introduced flight education to over 400 colleges and universities throughout the United States (Wilson, 1979).

The post-WTS/World War II era led to the formation of the National Association of University Administrators of Aviation Education (NAUAAE). Its purpose was to promote collegiate aeronautical education and, at its first annual meeting in 1948, the NAUAAE adopted a mission statement focused on educating:

A new generation of youth, graduating from the high schools and colleges each year, with a thorough grounding in and understanding of the airplane and its social, scientific, political, and economic influences upon living will, through the years, establish an informed public opinion on aviation which will go far toward eliminating many of the present day problems which beset the aviation industry and the national defense (University Aviation Association (UAA) Timeline).

The following year NAUAAE changed its name to the University Aviation Association (UAA) and currently represents 107 institutions of higher education engaged in aviation education. Known now as the "The Voice of Collegiate Aviation," the UAA represents the interests of aviation educators worldwide (UAA Timeline; The Collegiate Aviation Review (CAR), 2004).

As the UAA developed and matured, its members became increasingly interested in formally accrediting collegiate aviation programs and maturing the discipline by establishing a peer-reviewed, aviation periodical devoted to providing a "national vehicle for the dissemination of knowledge relative to aviation among institutions of higher education and governmental and industrial organizations in the aviation/aerospace field" (CAR, 2004, p. 6) . A call for papers in 1985 became the genesis of the peer-reviewed Collegiate Aviation Review that has continued to the present (UAA Timeline).

It is only in the last twenty years that other non-engineering aviation scholarly research journals began to appear. Prior to the recent emergence of new scholarly journals, aviation education researchers had only a limited number of publishing opportunities available to them. Most were found in related disciplines. In 
addition, those who aspired to teach and research in aviation would do so in aviation programs that resided in diverse colleges and academic units. Some would find themselves in colleges of engineering, others in colleges of education, while others might be faculty members in a college of technology or arts and sciences. The lack of consistency and clear definition in aviation education within academia forced many faculty members to publish in journals associated with disciplines "in which their programs [were] aligned” (Kaps \& Phillips, 2004, p. 27).

This lack of definition and recent emergence of aviation peer-reviewed journals has led some to define aviation education as an "emerging discipline." This is especially true when comparing it to well-established disciplines such as theology, philosophy and mathematics. Claire Aitchison, writing for the Proceedings of the National Language and Academic Skills Conference at La Trobe University, Australia, described non-engineering aviation education in that country as an emerging discipline and pointed out that its "defining characteristic" was its "need to be seen as viable, credible and academically rigorous" (2000, p. 4).

Toulmin characterized a mature or "compact discipline" as a set of five interconnected elements. One such characteristic describes an established discipline as one that provides for discourse among its practitioners to critically review new concepts, continuously refine the discipline's underlying tenets and ultimately yield "disciplinary loci" (1971). Such debate is most often found in its scholarly journals and practitioner-focused publications. These publications then become a repository for its practitioners. As aviation education establishes itself in academia, it must continue to advance the discipline by creating a rich repository characterized by scholarship and inquiry.

\section{PURPOSE}

The purpose of this article is to define such a repository of aviation education scholarship by those engaged in its practice. Unlike traditional studies of this nature, which base evaluations on the academic prestige or the research impact of periodicals (e.g., Heischmidt \& Gordon, 1993;
Howard \& Nikolai, 1983), this study focuses on functional usefulness. Certainly, educators will have a direct interest in their peers' ratings of the periodicals in terms of research, outreach, and teaching merits (Gibson \& Hanna, 2003).

While academic-focused publications are of value to academe, traditional periodical evaluation studies have focused narrowly on the research value of peer reviewed academic journals (Benjamin \& Brenner, 1974; Browne \& Becker, 1991; Heischmidt \& Gordon, 1993; Hult, Neese, \& Bashaw, 1997; Malouin \& Outreville, 1987). More recent studies have widened the scope of evaluations, citing two main reasons. First, academic- and practitionerfocused publications both benefit educators and warrant evaluation, and second, many publications are broad based and should not be judged exclusively on their research value (Hull \& Wright, 1990; Hult, Neese, \& Bashaw, 1997; Mason \& Steagall, 1997; Gibson \& Hanna, 2003).

The analysis of periodical usefulness is presented in four major sections. The first two sections, Previous Research and Research Design, lay the foundation for the study. The third section, Results and Discussion, reveals results of the study, including periodical ratings, group comparisons, a bias analysis, and usefulness index scores. Finally the Implications and Discussion section presents insights gleaned from the study, its potential uses by key constituents, and its caveats.

\section{PREVIOUS PERIODICAL RESEARCH}

The evaluation of periodicals is neither a trivial topic nor one of exclusive interest to educators. Studies providing a benchmark of specialty periodicals can be used for a variety of purposes, in addition to those described above. The evaluation results can be used by practitioners to become more aware of valuable resources and information outlets (Fawcett, Vellenga, \& Truitt, 1995), university administrators to assess faculty research performance (Hull \& Wright, 1990), and periodical publishers to keep their editorial objectives and content in sync with reader needs (Gibson \& Hanna, 2003; Reichenstein \& Zivney, 1994).

Two previous aviation literature surveys have been published. The results of the first 
study, employing a "specialized computer research criterion and key informant interviews,” (Kapps \& Phillips, 2004, p. 25) were reproduced by the UAA (Truitt \& Kaps). The results were classified under various categories such as "Aviation Law Journalism," "Interdisciplinary Journals," and "Transportation Management Journals” (Directory of Scholarly Journals which Publish Non-Engineering Aviation Research, 1995). The Directory made no attempt to rate the journals. "Publishing Aviation Research: A Literature Review of Scholarly Journals” by Kaps and Phillips is a replication and expansion of Turitt and Kaps' original work. As in the first, it does not attempt to rate aviation periodicals but, instead, grouped them into four broad categories: "Aviation specific academically peer reviewed," "Nonaviation specific academically peer reviewed," "Aviation related journals refereed by an editorial board," and publications that do not claim to be refereed (p. 28-29).

Survey-based studies have been widely used to perform evaluations of relevant periodicals in other disciplines. In many of these studies, experts in the particular discipline evaluated periodicals using individual Likert scale assessments of quality, prestige, impact, relevance, timeliness, and/or readability (Coe \& Weinstock, 1983; Heischmidt \& Gordon, 1993; Hull \& Wright, 1990; Malouin \& Outreville, 1987).

A limited number of non-aviation studies have factored usage, readership, or popularity into their analysis (Browne \& Becker, 1991; Hult, Neese, \& Bashaw, 1997; Luke \& Doke, 1987). These more expansive studies provide stronger and more reliable evaluations of periodical importance (Hult, Neese, \& Bashaw, 1997).

Previous studies have also targeted university faculty and administrators in the relevant discipline as the survey population (Heischmidt \& Gordon, 1993; Howard \& Nikolai, 1983). These individuals are viewed as having the greatest familiarity with and expertise regarding the periodicals, and thus constitute the most appropriate population for evaluation studies. For example, the most recent studies of logistics periodicals targeted United States college and university professors in the logistics and transportation field (Fawcett, Vellenga, \&
Truitt, 1995; Ferguson, 1975; Gibson \& Hanna, 2003).

\section{RESEARCH DESIGN}

Based on our goals and previous research, an expert opinion survey was developed. Key activities included: identifying relevant periodicals, designing the survey instrument, and defining the survey population (Gibson \& Hanna, 2003).

First, an integrated list of 44 research journals and practitioner-oriented publications was compiled based on the two previous aviation journal studies (Kaps \& Phillips, 2004; Truitt \& Kaps, 1995) as well as input from 14 aviation educators. Additional suggestions resulted in a list of 56 publications. Additional information regarding these periodicals (official title, publisher name and location, and ISSN) was assembled and an alphabetized list of the periodicals and related information was created for inclusion in the survey (Appendix A).

Next, a web-based survey instrument was developed, tested, and revised. The questionnaire instructed respondents to identify up to ten periodicals that they use most frequently for their aviation research activities. Respondents were then asked to assess the merit of these periodicals using a five-point scale $(1=$ low and $5=$ high). The factors used in this assessment were the periodical's quality of articles, its value to their aviation research activities, and its impact on the discipline. The same process and similar factors were used to collect information regarding the respondents' use and perceptions of periodicals for aviation outreach activities and aviation teaching activities, respectively. Additionally, the respondents were asked to assess the statements "I am very familiar with this periodical" and "I regularly read this periodical" for 56 publications using a five-point scale $(1=$ strongly disagree and $5=$ strongly agree) (Gibson \& Hanna, 2003) (see Appendix B).

The targeted survey population was identified by using the UAA's "Professional Membership List." The comprehensive list contains 219 U.S. and international aviation educators with 213 of those listing email addresses (97\%). Because the majority of population had access to email and the internet, we chose a web-based survey format (Lyons, 
Cude, Gutter, \& Lawrence, 2003). An email message containing survey instructions and a link to the web-based survey was sent to each member inviting them to participate in the survey (Appendix C). Of the 213 email messages sent, six email addresses were incorrect or no longer in use. Of the total 219 members, 205 (93\%) had messages delivered to their email accounts. The effective sample size, then, was 205.

The survey site disallowed duplicate entries and was left "open” for eight weeks. There were thirty-one individual responses or, a response rate of $15.1 \%$. The response rate for $\mathrm{PhD}$ granting institutions was $54.2 \%$ (representatives from 13 of 24 institutions responded). Although the response rate is less than optimal, it is, based on the consistency of the results, sufficient to draw meaningful conclusions (Lessler \& Kalsbeek, 1992, 116-117). Table 1 provides a breakdown of the respondents by category.

\section{RESULTS AND DISCUSSION}

The respondents identified and evaluated their ten most widely used periodicals in each education-related activity. In total, three top ten usage lists were created - one for research, outreach, and teaching. These lists included 56 periodicals from the periodical information sheet distributed with the survey and eight others identified by individual respondents.

In many instances, a limited number of respondents identified and evaluated a particular publication. To promote effective statistical analysis, and provide a balanced periodical ranking, only those publications identified in greater than ten percent of the three top ten usage lists are included in this examination. Summary of those periodicals identified is

Table 1. Survey Participation Demographics provided in Table 2. All periodicals involved in the research are listed in Appendix A.

A key influence on the respondents' top ten lists appeared to be each periodical's subject matter. Periodicals reflecting a wide breadth of aviation education issues were prominent in the rankings. These titles also received high and consistent mean merit ratings for quality, contribution to the discipline, and usefulness to research.

In contrast, periodicals reflecting a limited area of aviation or a complementary field received fewer respondent top ten rankings. They also tended to receive more moderate merit ratings across the three areas of evaluation. Still, these related field periodicals warranted inclusion in Table 2.

\section{Demographic Group Comparisons}

One objective of the research was to assess the institutional focus on research versus teaching. $\mathrm{T}$ tests on the periodical merit ratings from Table 2 were calculated to examine differences in the merit ratings among the respondents based on the following categories:

- Tenured faculty versus non-tenured faculty

- Research/balanced institution faculty versus teaching institution faculty

T-tests revealed significant differences in mean merit ratings for only three periodicals, although analyses were conducted across categories for each dimension (quality, outreach, and research). In general, there is consensus between the different categories regarding the merit of the most frequently used periodicals. Table 3 reflects the significant t-test results.

\begin{tabular}{cll}
\hline & Frequency (n=31) & Percentage \\
\hline Respondent Type & & \\
\hline Tenured/tenure track faculty & 23 & $74.2 \%$ \\
\hline Non-tenured faculty & 8 & $25.8 \%$ \\
\hline Institutional Mission Type & & \\
\hline Research & 2 & $6.4 \%$ \\
\hline Balanced & 15 & $48.4 \%$ \\
\hline Teaching & 14 & $45.2 \%$ \\
\hline
\end{tabular}


Table 2. Aviation Educators' Assessment of Periodicals

\begin{tabular}{|c|c|c|c|c|}
\hline Title & $\begin{array}{c}\text { Number of } \\
\text { Appearances } \\
\text { in } \\
\text { Respondents' } \\
\text { Lists } \\
\end{array}$ & $\begin{array}{c}\text { Quality of } \\
\text { Research } \\
\text { Mean* }\end{array}$ & $\begin{array}{c}\text { Contribution } \\
\text { to Outreach } \\
\text { Mean }\end{array}$ & $\begin{array}{c}\text { Usefulness } \\
\text { to } \\
\text { Teaching } \\
\text { Mean }\end{array}$ \\
\hline Collegiate Aviation Review & 21 & 4.46 & 4.00 & 3.80 \\
\hline Aviation Week and Space Technology & 18 & 4.17 & 4.33 & 4.00 \\
\hline Journal of Air Transportation & 18 & 4.44 & 4.63 & 4.44 \\
\hline Journal of Aviation/Aerospace Education and Research & 16 & 3.80 & 4.00 & 3.93 \\
\hline International Journal of Applied Aviation Studies & 16 & 4.07 & 4.14 & 4.07 \\
\hline International Journal of Aviation Psychology & 8 & 4.88 & 4.75 & 4.75 \\
\hline AOPA Flight Training & 10 & 3.30 & 3.40 & 2.60 \\
\hline Aviation, Space, and Environmental Medicine & 6 & 4.43 & 4.29 & 4.29 \\
\hline $\begin{array}{l}\text { Human Factors and Aerospace Safety (Journal of } \\
\text { Human Factors) }\end{array}$ & 6 & 4.33 & 4.33 & 4.33 \\
\hline $\begin{array}{l}\text { ICAO Journal (International Civil Aviation } \\
\text { Organization) }\end{array}$ & 6 & 3.33 & 3.33 & 3.33 \\
\hline Air Traffic Control Quarterly & 4 & 3.00 & 3.00 & 3.50 \\
\hline $\begin{array}{l}\text { Transportation Research Record: Journal of } \\
\text { Transportation Research Board }\end{array}$ & 4 & 3.75 & 3.50 & 3.00 \\
\hline $\begin{array}{l}\text { Aviation Security International: The Journal of Airport } \\
\text { and Airline Security }\end{array}$ & 2 & 5.00 & 5.00 & 5.00 \\
\hline $\begin{array}{l}\text { Human Factors: Journal of Human Factors and } \\
\text { Ergonomics Society }\end{array}$ & 2 & 4.50 & 5.00 & 5.00 \\
\hline Journal of Air Transport Management & 2 & 4.50 & 4.00 & 4.50 \\
\hline Journal of Air Law and Commerce & 2 & 4.50 & 4.00 & 3.50 \\
\hline $\begin{array}{l}\text { ATEA Journal (American Technical Education } \\
\text { Association) }\end{array}$ & 2 & 4.00 & 3.50 & 2.00 \\
\hline Airport & 2 & 3.50 & 3.50 & 3.50 \\
\hline Air and Space Law & 2 & 2.00 & 2.00 & 1.50 \\
\hline Transportation Quarterly & 1 & 5.00 & 5.00 & 5.00 \\
\hline Journal Experimental Psychology: Applied & 1 & 5.00 & 5.00 & 3.00 \\
\hline $\begin{array}{l}\text { Human Factors and Aerospace Safety: An International } \\
\text { Journal }\end{array}$ & 1 & 5.00 & 4.00 & 4.00 \\
\hline $\begin{array}{l}\text { Journal of Aircraft (American Institute of Aeronautics } \\
\text { and Astronautics }\end{array}$ & 1 & 5.00 & 4.00 & 4.00 \\
\hline
\end{tabular}


Table 2 (Continued). Aviation Educators' Assessment of Periodicals

\begin{tabular}{lllll}
\hline Journal of Transportation Geography & 1 & 4.00 & 4.00 & 4.00 \\
Transportation Research & 1 & 3.00 & 4.00 & 4.00 \\
Journal of Human Performance in Extreme & 1 & 3.00 & 1.50 & 1.00 \\
Environments & & & & \\
* Mean across three factors based on 5 point scales: 1 = \\
Low to 5 = High
\end{tabular}

Table 3. Demographic Group Analysis Results

\begin{tabular}{lcccc}
\hline \multirow{2}{*}{ Periodical Title } & \multicolumn{2}{c}{$\begin{array}{c}\text { Significant Difference in } \\
\text { Activity Merit Means }\end{array}$} & Activity \\
\hline Collegiate Aviation Review & 4.74 & 3.79 & Non-Tenured \\
\cline { 2 - 3 } & 4.68 & 3.72 & Research \\
Journal of Air Transportation & & Research
\end{tabular}

\section{Research/Balanced Institutions}

Journal of Air Transportation

Aviation Week and Space

Technology
4.54

3.68

\section{Teaching \\ Institutions}

3.84

4.31
Teaching

Teaching

Notes: All differences are significant at $\mathrm{p}<.05$

* Mean across three factors based on 5 point scales: $1=$ Low $5=$ High

\section{Periodical Usefulness Index Development}

The final objective of the research was to develop an overall assessment of each periodical's usefulness across the three dimensions of evaluation. This assessment is based on the respondents' top ten merit ratings.

Periodical usefulness is characterized as a combination of its merit and usage across the three key educational activities. The usefulness index score for each periodical was developed using the data contained in the four columns of Table 2. Each category mean was converted to a 25-point scale item in a 100-point usefulness index as follows:

Usefulness Index Score $=$ Usage Score + Research Merit Score + Outreach Merit Score + Teaching Merit Score

Where: Usage Score $=$ mean readership activity level x 5

Research Merit Score $=$ mean research merit rating x 5

Outreach Merit Score $=$ mean outreach merit rating x 5

Teaching Merit Score $=$ mean teaching merit rating $\mathrm{x} 5$

Frequency weighting $=$ the number of respondents citing the journal in the top ten divided by the total number of respondents.

The usage and merit scores are summed and then multiplied by the frequency weighting to determine the usefulness index score.

The results of usefulness index score calculations are provided in Table 4.

Table 4 provides a number of noteworthy results and interesting insights into the perceptions 
of the survey respondents. First and foremost is the usefulness index score attained by the Collegiate Aviation Review. Respondents perceive it as the most useful in terms of research making it the top aviation education academic journal.

Another striking result is the respondents' strong perceptions and extensive use of publications that are not traditional peer-reviewed journals. Unlike other disciplines where few if any non-academic journals achieve high rankings in these types of studies, aviation educators rate such publications highly. In fact, two of the top ten publications found in Table 4 rely upon invited articles, editorially reviewed articles, and articles by professional journalists. Aviation Week and Space Technology stands out among these publications, achieving the second highest usefulness index score. In addition, the usefulness index shows the respondents' proclivity to focus on broad-based issues affecting aviation education and air transportation. The expanding scope of applied aviation research, outreach, and teaching activities enhances the usefulness of such periodicals to aviation educators.

\section{IMPLICATIONS AND CONCLUSIONS}

The research presented here departs from the normal approach to journal evaluation. Two differences are worth noting- the combined evaluation of peer-reviewed journals and trade publications, and the inclusion of an overall usefulness index across three independent perspective ratings.

\section{User Implications}

Although the study population consisted exclusively of aviation educators, the usefulness index scores and related rankings present a perspective of value to various groups with interests in the discipline. These would include educators, practitioners, university administrators, and periodical administrators. The following perspectives on the varied interests are provided:

Table 4. Periodical Usefulness Index Scores

\begin{tabular}{lcccccc}
\hline Title & $\begin{array}{c}\text { Usage } \\
\text { Score }\end{array}$ & $\begin{array}{c}\text { Research } \\
\text { Merit } \\
\text { Score }\end{array}$ & $\begin{array}{c}\text { Outreach } \\
\text { Merit } \\
\text { Score }\end{array}$ & $\begin{array}{c}\text { Teaching } \\
\text { Merit } \\
\text { Score }\end{array}$ & $\begin{array}{c}\text { Frequency } \\
\text { Weighting }\end{array}$ & $\begin{array}{c}\text { Usefulness } \\
\text { Index } \\
\text { Score }\end{array}$ \\
\hline $\begin{array}{l}\text { Collegiate Aviation Review } \\
\text { Aviation Week and Space }\end{array}$ & 23.72 & 22.30 & 20.00 & 19.00 & .68 & 57.8 \\
$\begin{array}{l}\text { Technology } \\
\text { Journal of Air Transportation }\end{array}$ & 15.21 & 22.2 & 23.15 & 22.20 & .58 & 48.6 \\
$\begin{array}{l}\text { International Journal of Applied } \\
\text { Aviation Studies }\end{array}$ & 16.01 & 20.35 & 20.70 & 20.35 & .52 & 40.2 \\
Journal of Aviation/Aerospace & 16.84 & 19.00 & 20.00 & 19.65 & .52 & 39.2 \\
$\begin{array}{l}\text { Education and Research } \\
\text { International Journal of Aviation }\end{array}$ & 12.32 & 24.4 & 23.75 & 23.75 & .26 & 21.9 \\
$\begin{array}{l}\text { Psychology } \\
\text { AOPA Flight Training }\end{array}$ & 14.93 & 16.50 & 17.00 & 13.00 & .32 & 19.7 \\
$\begin{array}{l}\text { Human Factors and Aerospace } \\
\text { Safety (Journal of Human }\end{array}$ & 13.64 & 21.65 & 21.70 & 21.65 & .19 & 14.9 \\
$\begin{array}{l}\text { Factors) } \\
\text { Aviation, Space, and }\end{array}$ & & & & & & \\
$\begin{array}{l}\text { Environmental Medicine } \\
\text { ICAO Journal (International Civil }\end{array}$ & 14.33 & 16.65 & 16.65 & 16.65 & .19 & 12.2 \\
$\begin{array}{l}\text { Aviation Organization) } \\
\text { Air Traffic Control Quarterly }\end{array}$ & 13.81 & 15.00 & 3.00 & 17.50 & .13 & 6.41 \\
$\begin{array}{l}\text { Transportation Research Record: } \\
\text { Journal of Transportation }\end{array}$ & 9.30 & 18.75 & 3.50 & 15.00 & .13 & 6.05 \\
\begin{tabular}{l} 
Research Board \\
\hline
\end{tabular} & & & & & & \\
\hline
\end{tabular}


Aviation educators - The broad spectrum of highly rated publications suggests that it is possible for aviation educators to find relevant information for their research, outreach, and teaching activities. In addition, aviation educators are not limited to narrowly defined topics or publication sources for presenting their research. The results imply that researchers can contribute significantly through varying types of publications. In addition, the results could be used as another means of benchmarking performance and developing a focused list of outlets for future publications.

Aviation practitioners - While management may not directly conduct research, management frequently is involved in training, sharing perspectives in conferences, undertaking collaborative initiatives, and other industryrelated endeavors. Hence the publication scores and rankings that contribute to teaching and outreach activities are of particular value. Being exposed to those publications found most valuable to their academic counterparts could help management improve the efficiency of their information searches and aid in obtaining effective instructional and outreach materials.

In addition, the research results can serve two other purposes for practitioners. First, Appendix A provides managers with an extensive list of relevant publications. This list can be consulted when making subscription purchase decisions. Second, the results provide insight regarding the research, outreach, and teaching focus of aviation educators. Management would find this information useful since they depend on academe to prepare future leaders for professional careers in aviation.

University administrators - In many institutions, department chairs and other administrators charged to evaluate aviation faculty performance lack familiarity with the field. This research provides an external source of information regarding the usefulness of peerreviewed aviation education journals. These usefulness ratings could be used as one of several inputs in the development of a reference list of research publications for their faculty. However, administrators should hesitate using these results solely as many prestigious journals simply do not have broad appeal and, as a result, did not receive a usefulness index score.
Appendix A reveals that some of these journals have strengths in a particular activity that should be recognized accordingly.

Administrators should also take note of the types of publications aviation educators find to be most useful. The results suggest that practitioner-focused periodicals and related field journals are important to not only research but the outreach and teaching responsibilities of most aviation education faculty. Additionally, article publications in these venues are valuable when considering applied scholarship according to the primary accrediting agency for university business programs (Association to Advance Collegiate Schools of Business International, 2001). Administrators should weigh this combination of peer value and intellectual contribution accordingly when evaluating faculty participation in these non-traditional forms.

Publications administrators - The limit of narrowly focused academic journals and practitioner publications in the rankings serves as a caution to publishers and editors. The influence of a wide spectrum of aviation issues on the respondents' activities may suggest a change in subscriptions and article submissions. Editors who have limited the scope of their publications may need to adapt to a change in trends so as to insure relevance to the discipline and financial viability. Strategic changes might include developing editions devoted to special topics, seeking opportunities to publish jointly with other periodicals, or electing a fundamental change in the publication's professional focus.

\section{Research Limitations}

Although efforts were made to achieve reliable, valid, and unbiased results, the structure of the sampling, the scope of publications considered, and the justification to generalize the research results represent possible limitations which the authors wish to acknowledge.

First, the sampling of aviation educators could be viewed as too narrow. However, given the research objective to evaluate publications relevant to the non-engineering aviation education discipline - aviation educators were the logical target population. With the response rate achieved, the authors are of the view that that the results sufficiently represent aviation 
educators' perceptions of journal usefulness for conducting aviation education research, outreach, and teaching activities.

Second, the inclusion of some non-aviation journals in the study could be viewed as problematic. Considering the survey population, it was expected that widely distributed aviation periodicals would receive higher usefulness index scores than non-aviation periodicals because of their application and relevance. Hence, the authors made no direct comparisons of the usefulness indices; the mere appearance of these related field journals among those listed underscores the positive findings.

Considering the original focus of the research, the results should not be broadly interpreted. The rankings may not represent the periodical usefulness views of educators who work primarily in other fields but periodically are involved in aviation education activities. Their perceptions of aviation and interest areas may lead these educators to use a vastly different group of periodicals. Also, the usefulness index scores apply specifically to aviation education activities and are not necessarily transferable to related disciplines. The scores reported in this study do not necessarily reflect journals' value for other management activities.

\section{Future Directions}

While these limitations do not detract from the value of the current study, they suggest two opportunities for future research. First, expanding the survey population to include aviation educators from different cultural and organizational environments and aviation and air transport practitioners would strengthen the depth of the current enquiry. Second, a study spanning two to three years may identify trends and changes in aviation education periodical usefulness and would be useful to aviation educators given the lack of research history within the discipline. New publications and information outlets will come forth to play a significant role in aviation education educators' activities.

In summary, this research constitutes an initial effort to identify periodical usefulness for the discipline, it aids in evaluating new periodicals that may emerge, and it helps focus on non-engineering, aviation-related issues. It initiates a crucial step in achieving the academic status of a recognizable discipline by defining periodical usefulness, providing crucial information for key stakeholders charged with faculty evaluation, and without question, it suggests opportunities for extending the research in order to gain a longitudinal perspective and a view of the evolving scope of the discipline. 


\section{REFERENCES}

Aitchison, C. (2000). "Learning Centres [sic]—From Calling the Fixer to Building A Better Product: A Case Study of Needs Based Subject Development.” In K Chanock (Ed.), Sources of Confusion: Refereed Proceedings of the National Language and Academic Skills Conference, (pp. 4-5). Bundoora, Australia: La Trobe University.

Association to Advance Collegiate Schools of Business (2001). "Standards for Business Accreditation," retrieved February 1, 2002 from: http://www.aacsb.edu/accreditation/business/BusinessStandards2000.pdf.

Benjamin, J., \& Brenner, V. (1974). "Perceptions of Journal Quality,” The Accounting Review, 49(2), 360-362.

Browne, W. G., \& Becker, B. W. (1991). “A Longitudinal Study of Marketing Journal Familiarity and Quality,” AMA Educators' Proceedings: Enhancing Knowledge Development in Marketing, Chicago: American Marketing Association, pp. 702-710.

Coe, R. C., \& Weinstock, I. (1983). "Evaluating Finance Journals: The Department Chairperson's Perspective,” Journal of Finance Research, 6(4) 345-349.

Council of Logistics Management, “Logistics Program Coursework,” retrieved December 1, 1999 from: http://www.clm1.org/education/coursework.asp.

Cudd, M., \& Morris, J. (1988). “Bias in Journal Ratings.” The Financial Review, 23(1), 117-125.

Fawcett, S. E., Vellenga, D. B., \& Truitt, L. J. (1995). “An Evaluation of Logistics and Transportation Professional Organizations, Programs, and Publications,” Journal of Business Logistics, 16(1), 299314.

Ferguson, W. (1975). “An Evaluation of Journals that Publish Business Logistics Articles," Transportation Journal, 22(4), 69-72.

Gentry, J. J., Allen, B J., \& Vellenga, D. B. (1995). "Affiliation of Authors in Transportation and Logistics Academic Journals- Revisited,” Transportation Journal, 35(3), 54-62.

Gibson, B. J., \& Hanna, J. B. (2003). "Periodical Usefulness: The U.S. Logistics Educator Perspective," Journal of Business Logistics, 24(1), 221-240.

Heischmidt, K. A., \& Gordon, P. (1993). "Rating Marketing Publications: Impact of Accreditation and Publication History,” Journal of Education for Business, 68(3), 152-158.

Howard, T., \& Nikolai, L. (1983). "Attitude Measurement and Perceptions of Accounting Faculty Publication Outlets,” The Accounting Review, 58(4), 765-776.

Hull, R. P., \& Wright, G. B. (1990). “Faculty Perceptions of Journal Quality: An Update,” Accounting Horizons, 4(1), 77-101.

Hult, G., Tomas, M., Neese, W. T., \& Bashaw, R. E. (1997). "Faculty Perceptions of Marketing Journals,” Journal of Marketing Education, 19(1), 37-53.

Johnson, R. (2005). From Cubs to Hawks: The Story of the Aircraft, Airfields and Training of the Tuskegee Airmen. Ft. Washington, PA: Eastern National.

Levin, J. R., \& Kratochwill, T. R. (1976). "The Name of the Journal Fame Game: Quality or Familiarity?” American Psychologist, 31(9), 673-674.

Lyons, A., Cude, B., Gutter, M., \& Lawrence, F. (2003). “Collecting Consumer Data Using Online Surveys," Consumer Interests Annual, 49, 1-3. 
Kaps, R., \& Phillips, E. (2004). "Publishing Aviation Research: A Literature Review of Scholarly Journals,” Journal of Aviation/Aerospace Education and Research, Fall 2004, 25.

Lessler, J. T., \& Kalsbeek, W. D. 1992. Nonsampling Error in Surveys. New York: Wiley-Interscience

Luke, R. H., \& Doke, E R. (1987). "Marketing Journal Hierarchies: Faculty Perceptions, 1986-1987,” Journal of the Academy of Marketing Science, 15(1), 74-78.

Malouin, Jean-Louis, \& Outreville, J. F. (1987). “The Relative Impact of Economics Journals: A CrossCountry Survey and Comparison,” Journal of Economics and Business, 39(3), 267-277.

Mason, P. M., \& Steagall, J. W. (1997). "Economics Journal Rankings By Type of School: Perceptions Versus Citations,” Quarterly Journal of Business and Economics, 36(1), 69-81

Miyazaki, A. D., Phillips, J. K., \& Phillips, D. M. (1999), "Twenty Years of JBL: An Analysis of Published Research,” Journal of Business Logistics, 20(2), 1-19.

Peery, J. C., \& Adams, G. R. (1981), “Qualitative Ratings of Human Development Journals,” Human Development, 24(5), 312-319.

Preston, E. (Ed.) (1998). FAA Historical Chronology: Civil Aviation and the Federal Government 19261996. Washington, D.C.: U.S. Department of Transportation, Federal Aviation Administration, pp. 22-23.

Toulmin, S. (1972). Human Understanding, (Vol. 1). Oxford: Clarendon Press, pp. 371-382.

University Aviation Association (2004). Directory of Scholarly Journals which Publish Non-Engineering Aviation Research. Auburn, AL: University Aviation Association.

University Aviation Association (2004). "Statement of Objectives," The Collegiate Aviation Review (CAR), 22(1), 8.

University Aviation Association. University Aviation Association Historical Timeline, Unpublished Manuscript.

Wilson, J. R. M. (1979), Turbulence Aloft: The Civil Aeronautics Administration Amid Wars and Rumors of Wars 1938-1953. Washington, D.C.: U.S. Department of Transportation, Federal Aviation Administration, pp. 96-102.

Zivney, T. L., \& Reichenstein, W. (1994), “The Pecking Order in Finance Journals,” Finance Practice and Education, 4(2), 77-88. 


\title{
APPENDIX A - Journal Titles
}

\author{
Air \& Space Law \\ Air and Law \\ Air Safety Forum \\ Air Traffic Control Quarterly \\ Aircraft Technology Engineering \& Maintenance \\ Airport \\ Airport Press \\ Annals of Air and Space Law \\ AOPA Flight Training \\ ATEA Journal (American Technical Education Association) \\ ATEC Journal \\ Aviation Security International: The Journal of Airport \& Airline Security \\ Aviation, Space, and Environmental Medicine \\ Aviation Week \& Space Technology \\ Collegiate Aviation Review \\ Defense Transportation Journal \\ Human Factors and Aerospace Safety (Journal of Human Factors) \\ Human Factors and Aerospace Safety: an international journal \\ Human Factors: the journal of the human factors and ergonomics society \\ I C A O Journal: (International Civil Aviation Organization) \\ IEEE Transactions on Systems, Man, and Cybernetics \\ International Journal of Applied Aviation Studies \\ International Journal of Aviation Psychology \\ International Journal of Human Factors Modelling and Simulation \\ International Journal of Industrial Engineering: theory, applications and practice \\ Journal of Advanced Transportation \\ Journal of Air Law and Commerce \\ Journal of Air Transport Management \\ Journal of Air Transportation \\ Journal of aircraft (American Institute of Aeronautics and Astronautics) \\ Journal of Aviation/Aerospace Education \& Research \\ Journal of Avionics Education \\ Journal of Experimental Psychology: Applied \\ Journal of Hospitality and Tourism Education \\ Journal of Human Performance in Extreme Environments \\ Journal of Industrial Engineering \\ Journal of Transportation Geography \\ Journal of Transportation Law, Logistics and Policy \\ Journal of Transportation Management \\ Journal of Transportation Research Forum \\ Journal of Travel and Tourism Marketing \\ Journal of Travel Research \\ Knowledge, Technology \& Policy \\ Lawyer Pilot's Bar \\ Online Journal of Space Communications \\ 6 The Air and Space Lawyer \\ 47 Tourism Management \\ 48 Transport Management \\ 49 Transport Policy \\ 50 Transport Reviews \\ 51 Transportation Journal \\ 52 Transportation Law Journal \\ 53 Transportation Practitioners Journal \\ 54 Transportation Quarerly \\ 55 Transportation Research \\ 56 Transportation Research Record: Journal of the Transportation Research Board
}




\section{APPENDIX B}

EVALUATING THE USE OF AVIATION JOURNALS FOR RESEARCH, TEACHING AND OUTREACH ACTIVITY

1. Please identify the ten periodicals that you use most frequently in your research activities (e.g., generating research agenda, conducting literature review, etc.). Then rate each periodical on the factors provided in each column.

\begin{tabular}{|c|c|c|c|}
\hline $\begin{array}{l}\text { Pick a Journal title from the drop down list or if not listed please } \\
\text { provide the title in the text box. }\end{array}$ & $\begin{array}{l}\text { Quality of articles } \\
\text { Low } \stackrel{\text { High }}{\longleftrightarrow}\end{array}$ & \begin{tabular}{|c|}
$\begin{array}{l}\text { Impact on } \\
\text { discipline }\end{array}$ \\
Low $\longleftrightarrow$ High
\end{tabular} & 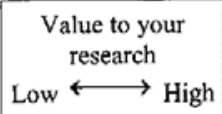 \\
\hline $\begin{array}{l}\text { Pick One } \\
\text { Title: }\end{array}$ & $\begin{array}{lllll}1 & 2 & 3 & 4 & 5 \\
0 & 0 & 0 & 0 & 0\end{array}$ & $\begin{array}{lllll}1 & 2 & 3 & 4 & 5 \\
0 & 0 & 0 & 0 & 0\end{array}$ & $\begin{array}{lllll}1 & 2 & 3 & 4 & 5 \\
0 & 0 & 0 & 0 & 0\end{array}$ \\
\hline $\begin{array}{l}\text { Pick One } \\
\text { Title: }\end{array}$ & $\begin{array}{lllll}1 & 2 & 3 & 4 & 5 \\
0 & 0 & 0 & 0 & 0\end{array}$ & $\begin{array}{lllll}1 & 2 & 3 & 4 & 5 \\
0 & 0 & 0 & 0 & 0\end{array}$ & $\begin{array}{lllll}1 & 2 & 3 & 4 & 5 \\
0 & 0 & 0 & 0 & 0\end{array}$ \\
\hline$\left\{\begin{array}{l}\text { Pick One } \\
\text { Title: }\end{array}\right.$ & $\begin{array}{lllll}1 & 2 & 3 & 4 & 5 \\
0 & 0 & 0 & 0 & 0\end{array}$ & $\begin{array}{lllll}1 & 2 & 3 & 4 & 5 \\
0 & 0 & 0 & 0 & 0\end{array}$ & $\begin{array}{lllll}1 & 2 & 3 & 4 & 5 \\
0 & 0 & 0 & 0 & 0\end{array}$ \\
\hline $\begin{array}{l}\text { Pick One } \\
\text { Title: }\end{array}$ & $\begin{array}{lllll}1 & 2 & 3 & 4 & 5 \\
0 & 0 & 0 & 0 & 0\end{array}$ & $\begin{array}{lllll}1 & 2 & 3 & 4 & 5 \\
0 & 0 & 0 & 0 & 0\end{array}$ & $\begin{array}{lllll}1 & 2 & 3 & 4 & 5 \\
0 & 0 & 0 & 0 & 0\end{array}$ \\
\hline $\begin{array}{l}\text { Pick One } \\
\text { Title: }\end{array}$ & $\begin{array}{lllll}1 & 2 & 3 & 4 & 5 \\
0 & 0 & 0 & 0 & 0\end{array}$ & $\begin{array}{lllll}1 & 2 & 3 & 4 & 5 \\
0 & 0 & 0 & 0 & 0\end{array}$ & $\begin{array}{lllll}1 & 2 & 3 & 4 & 5 \\
0 & 0 & 0 & 0 & 0\end{array}$ \\
\hline $\begin{array}{l}\text { Pick One } \\
\text { Title: }\end{array}$ & $\begin{array}{lllll}1 & 2 & 3 & 4 & 5 \\
0 & 0 & 0 & 0 & 0\end{array}$ & $\begin{array}{lllll}1 & 2 & 3 & 4 & 5 \\
0 & 0 & 0 & 0 & 0\end{array}$ & $\begin{array}{lllll}1 & 2 & 3 & 4 & 5 \\
0 & 0 & 0 & 0 & 0\end{array}$ \\
\hline $\begin{array}{l}\text { Pick One } \\
\text { Title: }\end{array}$ & $\begin{array}{lllll}1 & 2 & 3 & 4 & 5 \\
0 & 0 & 0 & 0 & 0\end{array}$ & $\begin{array}{lllll}1 & 2 & 3 & 4 & 5 \\
0 & 0 & 0 & 0 & 0\end{array}$ & $\begin{array}{lllll}1 & 2 & 3 & 4 & 5 \\
0 & 0 & 0 & 0 & 0\end{array}$ \\
\hline $\begin{array}{l}\text { Pick One } \\
\text { Title: }\end{array}$ & $\begin{array}{lllll}1 & 2 & 3 & 4 & 5 \\
0 & 0 & 0 & 0 & 0\end{array}$ & $\begin{array}{lllll}1 & 2 & 3 & 4 & 5 \\
0 & 0 & 0 & 0 & 0\end{array}$ & $\begin{array}{lllll}1 & 2 & 3 & 4 & 5 \\
0 & 0 & 0 & 0 & 0\end{array}$ \\
\hline $\begin{array}{l}\text { Pick One } \\
\text { Title: }\end{array}$ & $\begin{array}{lllll}1 & 2 & 3 & 4 & 5 \\
0 & 0 & 0 & 0 & 0\end{array}$ & $\begin{array}{lllll}1 & 2 & 3 & 4 & 5 \\
0 & 0 & 0 & 0 & 0\end{array}$ & $\begin{array}{lllll}1 & 2 & 3 & 4 & 5 \\
0 & 0 & 0 & 0 & 0\end{array}$ \\
\hline
\end{tabular}

2. Please identify the ten periodicals that you use most frequently in your outreach activities (e.g., advising organizations, developing training programs, preparing presentations, etc.). Then rate each periodical on the factors provided in each column.

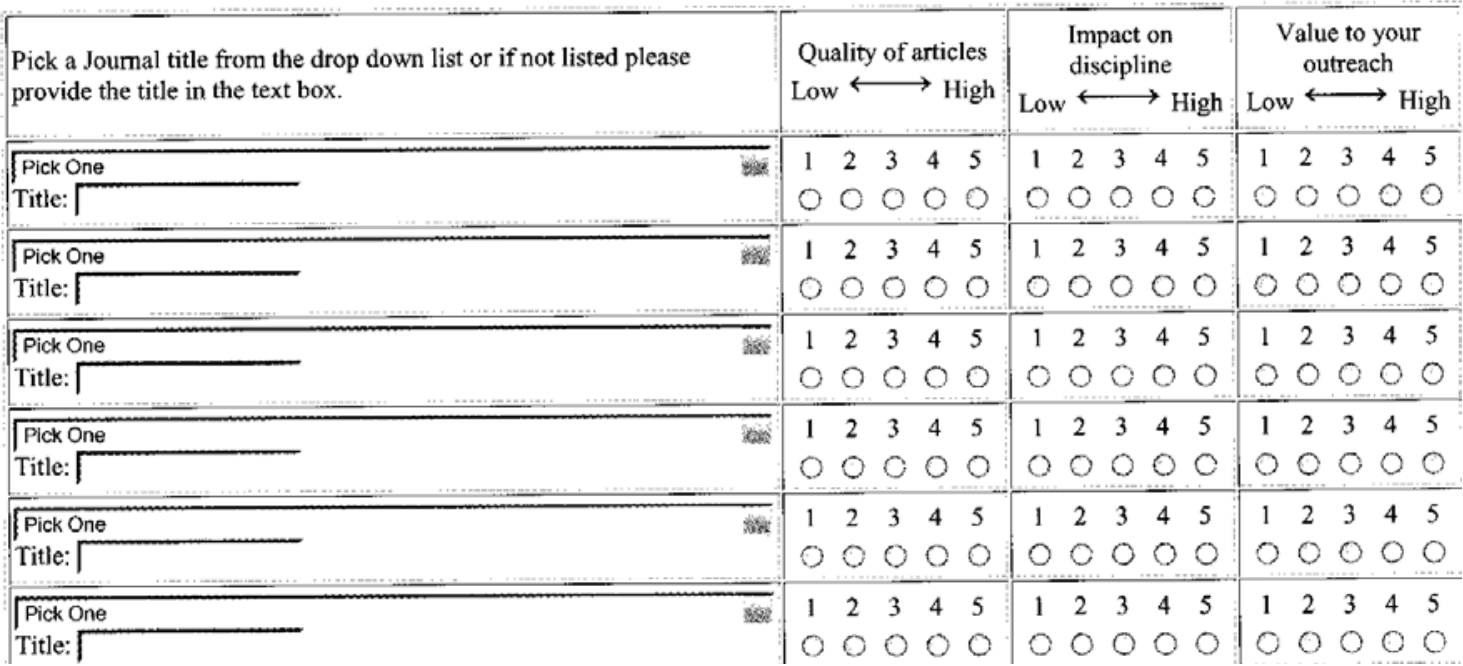




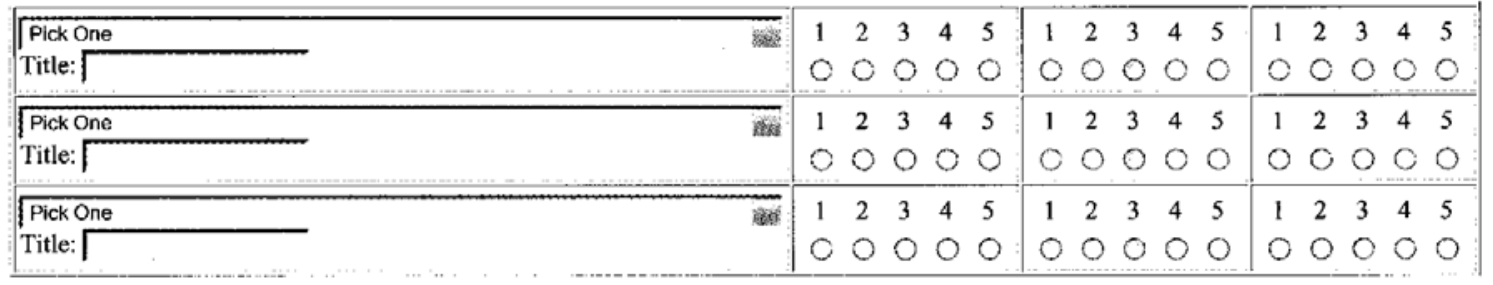

3.Please identify the type of course in which you most frequently use Aviation periodicals (other than textbooks). Note: if you do aot teach a particular course type, please do not consider it. (check one)

ODoctoral seminars

MBA/MSc courses

OUndergraduate

4. Using your response to Question 3 as your frame of reference, please identify the ten periodicals that you use most frequently in your teaching activities (e.g., preparing for class, assigning readings to students, etc). Then rate each periodical on the factors provided in each column.

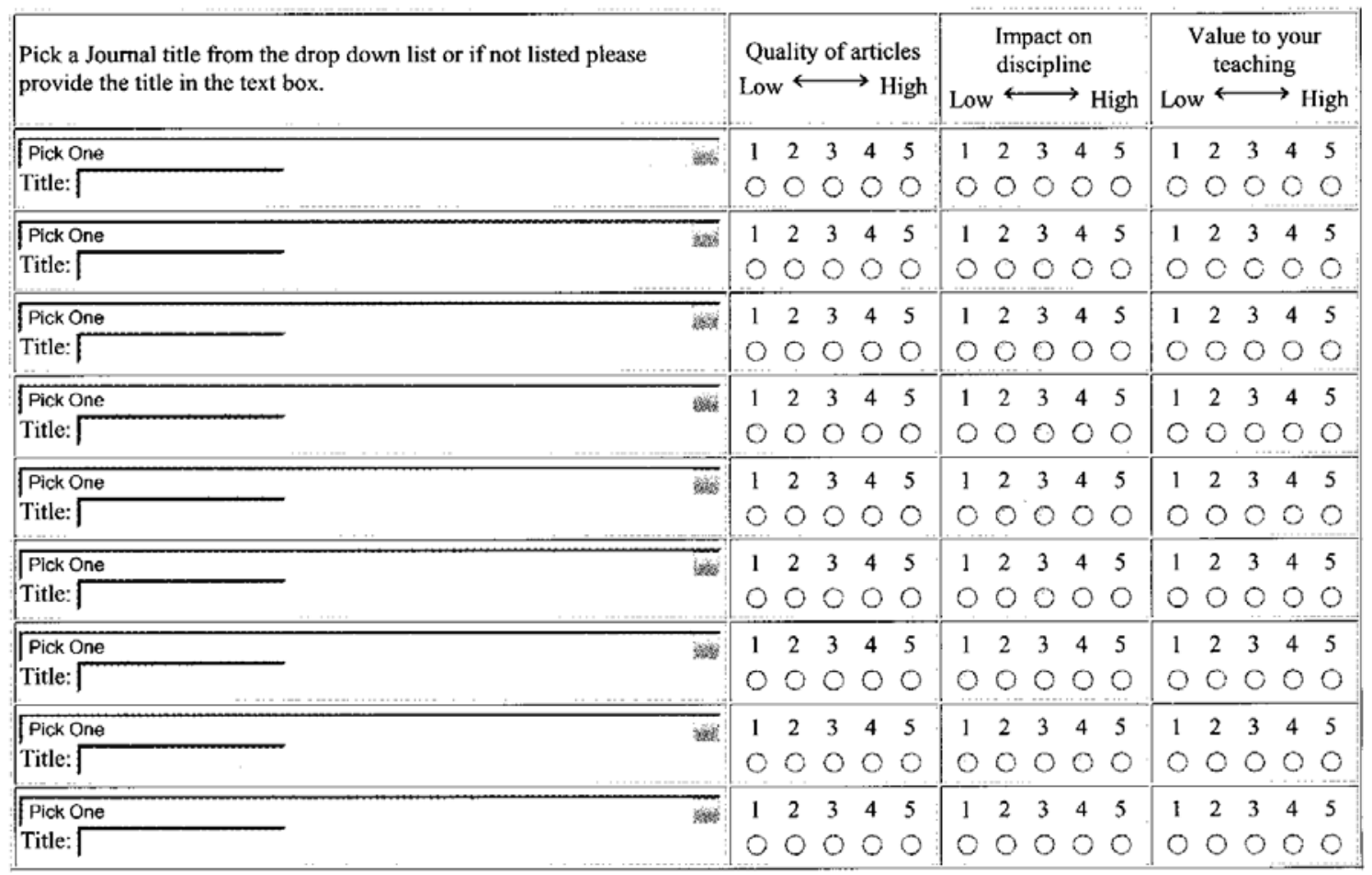

5. What type(s) of Aviation programs are offered at your institution? (check all that apply)

\section{$\square$ Doctoral seminars \\ DMBA/MSc courses \\ ๑Undergraduate}

6. What is the primary mission of your institution? (check one)

\section{Research \\ Teaching \\ OBalanced}


7. Is your program accredited by the Council on Aviation Accreditation (CAA)?

ĐYes

曰No

8. What is your academic rank? (check one)

Professor

Associate Professor

Assistant Professor

9. What is your tenure status? (check one)

OTenured

On tenure track

Not on tenure track

10. At which level(s) do you personally teach Aviation-related courses? (check all that apply)

$\square$ Doctoral seminars

[.] MBA/MSc courses

$\square$ Undergraduate

11. Please indicate your level of familiarity, readership, and involvement with the following periodicals by filling out the table. (Notes: if you have ne knowledge of a particular periodical, leave the entire row blank. If you have identified and evaluated other periodicals in this survey, use the blank rows at the end of the table to provide responses.

\begin{tabular}{|c|c|c|c|}
\hline \multirow{2}{*}{ Periodical Title } & $\begin{array}{l}\text { I am very familiar with this } \\
\text { periodical }\end{array}$ & \multirow{2}{*}{$\begin{array}{l}\text { I regularly read this periodical } \\
\text { Strongly } \longleftrightarrow \begin{array}{l}\text { Strongly } \\
\text { Disagree }\end{array}\end{array}$} & \multirow{2}{*}{$\begin{array}{l}\text { I am/have been } \\
\text { involved with this } \\
\text { periodical }\end{array}$} \\
\hline & $\begin{array}{l}\text { Strongly } \\
\text { Disagree }\end{array} \begin{array}{l}\text { Strongly } \\
\text { Agree }\end{array}$ & & \\
\hline Air \& Space Law & $\begin{array}{lllll}1 & 2 & 3 & 4 & 5 \\
0 & 0 & 0 & 0 & 0\end{array}$ & $\begin{array}{lllll}1 & 2 & 3 & 4 & 5 \\
0 & 0 & 0 & 0 & 0\end{array}$ & $\begin{array}{l}\square \text { Author } \\
\square \text { Reviewer }\end{array}$ \\
\hline Air and Law & $\begin{array}{lllll}1 & 2 & 3 & 4 & 5 \\
0 & 0 & 0 & 0 & 0\end{array}$ & $\begin{array}{lllll}1 & 2 & 3 & 4 & 5 \\
0 & 0 & 0 & 0 & 0\end{array}$ & $\begin{array}{l}\square \text { Author } \\
\square \text { Reviewer }\end{array}$ \\
\hline Air Safety Forum & $\begin{array}{lllll}1 & 2 & 3 & 4 & 5 \\
0 & 0 & 0 & 0 & 0\end{array}$ & $\begin{array}{lllll}1 & 2 & 3 & 4 & 5 \\
0 & 0 & 0 & 0 & 0\end{array}$ & $\begin{array}{l}\square \text { Author } \\
\square \text { Reviewer }\end{array}$ \\
\hline Air Traffic Control Quarterly & $\begin{array}{lllll}1 & 2 & 3 & 4 & 5 \\
0 & 0 & 0 & 0 & 0\end{array}$ & $\begin{array}{lllll}1 & 2 & 3 & 4 & 5 \\
0 & 0 & 0 & 0 & 0\end{array}$ & $\begin{array}{l}\square \text { Author } \\
\square \text { Reviewer }\end{array}$ \\
\hline $\begin{array}{l}\text { Aircraft Technology Engineering \& } \\
\text { Maintenance }\end{array}$ & $\begin{array}{lllll}1 & 2 & 3 & 4 & 5 \\
0 & 0 & 0 & 0 & 0\end{array}$ & $\begin{array}{lllll}1 & 2 & 3 & 4 & 5 \\
0 & 0 & 0 & 0 & 0\end{array}$ & $\begin{array}{l}\square \text { Author } \\
\square \text { Reviewer }\end{array}$ \\
\hline Airport & $\begin{array}{lllll}1 & 2 & 3 & 4 & 5 \\
0 & 0 & 0 & 0 & 0\end{array}$ & $\begin{array}{lllll}1 & 2 & 3 & 4 & 5 \\
0 & 0 & 0 & 0 & 0\end{array}$ & $\begin{array}{l}\square \text { Author } \\
\square \text { Reviewer }\end{array}$ \\
\hline Airport Press & $\begin{array}{lllll}1 & 2 & 3 & 4 & 5 \\
0 & 0 & 0 & 0 & 0\end{array}$ & $\begin{array}{lllll}1 & 2 & 3 & 4 & 5 \\
0 & 0 & 0 & 0 & 0\end{array}$ & $\begin{array}{l}\square \text { Author } \\
\square \text { Reviewer }\end{array}$ \\
\hline Annals of Air and Space Law & $\begin{array}{lllll}1 & 2 & 3 & 4 & 5 \\
0 & 0 & 0 & 0 & 0\end{array}$ & $\begin{array}{lllll}1 & 2 & 3 & 4 & 5 \\
0 & 0 & 0 & 0 & 0\end{array}$ & $\begin{array}{l}\square \text { Author } \\
\square \text { Reviewer }\end{array}$ \\
\hline
\end{tabular}




\begin{tabular}{|c|c|c|c|c|c|}
\hline AOPA Flight Training & $\begin{array}{lll}1 & 2 & 3 \\
0 & 0 & 0\end{array}$ & $\begin{array}{ll}4 & 5 \\
0 & 0\end{array}$ & $\begin{array}{lll}1 & 2 & 3 \\
0 & 0 & 0\end{array}$ & $\begin{array}{ll}4 & 5 \\
0 & 0\end{array}$ & $\begin{array}{l}\square \text { Author } \\
\square \text { Reviewer }\end{array}$ \\
\hline $\begin{array}{l}\text { ATEA Journal (American Technical } \\
\text { Education Association) }\end{array}$ & $\begin{array}{lll}1 & 2 & 3 \\
0 & 0 & 0\end{array}$ & $\begin{array}{ll}4 & 5 \\
0 & 0\end{array}$ & $\begin{array}{lll}1 & 2 & 3 \\
0 & 0 & 0\end{array}$ & $\begin{array}{ll}4 & 5 \\
0 & 0\end{array}$ & $\begin{array}{l}\square \text { Author } \\
\square \text { Reviewer }\end{array}$ \\
\hline ATEC Journal & $\begin{array}{lll}1 & 2 & 3 \\
0 & 0 & 0\end{array}$ & $\begin{array}{ll}4 & 5 \\
0 & 0\end{array}$ & $\begin{array}{lll}1 & 2 & 3 \\
0 & 0 & 0\end{array}$ & $\begin{array}{ll}4 & 5 \\
0 & 0\end{array}$ & $\begin{array}{l}\square \text { Author } \\
\square \text { Reviewer }\end{array}$ \\
\hline $\begin{array}{l}\text { Aviation Security International: The } \\
\text { Journal of Airport \& Airline Security }\end{array}$ & $\begin{array}{lll}1 & 2 & 3 \\
0 & 0 & 0 \\
\end{array}$ & $\begin{array}{ll}4 & 5 \\
0 & 0\end{array}$ & $\begin{array}{lll}1 & 2 & 3 \\
0 & 0 & 0\end{array}$ & $\begin{array}{ll}4 & 5 \\
0 & 0\end{array}$ & $\begin{array}{l}\square \text { Author } \\
\boxminus \text { Reviewer }\end{array}$ \\
\hline $\begin{array}{l}\text { Aviation, Space, and Environmental } \\
\text { Medicine }\end{array}$ & $\begin{array}{lll}1 & 2 & 3 \\
0 & 0 & 0\end{array}$ & $\begin{array}{ll}4 & 5 \\
0 & 0 \\
\end{array}$ & $\begin{array}{lll}1 & 2 & 3 \\
0 & 0 & 0\end{array}$ & $\begin{array}{ll}4 & 5 \\
0 & 0\end{array}$ & $\begin{array}{l}\square \text { Author } \\
\square \text { Reviewer }\end{array}$ \\
\hline Aviation Week \& Space Technology & $\begin{array}{lll}1 & 2 & 3 \\
0 & 0 & 0\end{array}$ & $\begin{array}{ll}4 & 5 \\
0 & 0\end{array}$ & $\begin{array}{lll}1 & 2 & 3 \\
0 & 0 & 0\end{array}$ & $\begin{array}{ll}4 & 5 \\
0 & 0\end{array}$ & $\begin{array}{l}\square \text { Author } \\
\square \text { Reviewer }\end{array}$ \\
\hline Collegiate Aviation Review & $\begin{array}{lll}1 & 2 & 3 \\
0 & 0 & 0\end{array}$ & $\begin{array}{ll}4 & 5 \\
0 & 0\end{array}$ & $\begin{array}{lll}1 & 2 & 3 \\
0 & 0 & 0\end{array}$ & $\begin{array}{ll}4 & 5 \\
0 & 0\end{array}$ & $\begin{array}{l}\square \text { Author } \\
\square \text { Reviewer }\end{array}$ \\
\hline Defense Transportation Journal & $\begin{array}{lll}1 & 2 & 3 \\
0 & 0 & 0\end{array}$ & $\begin{array}{ll}4 & 5 \\
0 & 0\end{array}$ & $\begin{array}{lll}1 & 2 & 3 \\
0 & 0 & 0\end{array}$ & $\begin{array}{ll}4 & 5 \\
0 & 0\end{array}$ & $\begin{array}{l}\text { [] Author } \\
\square \text { Reviewer }\end{array}$ \\
\hline $\begin{array}{l}\text { Human Factors and Aerospace Safety } \\
\text { (Journal of Human Factors) }\end{array}$ & $\begin{array}{lll}1 & 2 & 3 \\
0 & 0 & 0\end{array}$ & $\begin{array}{ll}4 & 5 \\
0 & 0\end{array}$ & $\begin{array}{lll}1 & 2 & 3 \\
0 & 0 & 0\end{array}$ & $\begin{array}{ll}4 & 5 \\
0 & 0\end{array}$ & $\begin{array}{l}\square \text { Author } \\
\square \text { Reviewer }\end{array}$ \\
\hline $\begin{array}{l}\text { Human Factors and Aerospace Safety: an } \\
\text { international journal }\end{array}$ & $\begin{array}{lll}1 & 2 & 3 \\
0 & 0 & 0\end{array}$ & $\begin{array}{ll}4 & 5 \\
0 & 0\end{array}$ & $\begin{array}{lll}1 & 2 & 3 \\
0 & 0 & 0 \\
\end{array}$ & $\begin{array}{ll}4 & 5 \\
0 & 0\end{array}$ & $\begin{array}{l}\square \text { Author } \\
\square \text { Reviewer }\end{array}$ \\
\hline $\begin{array}{l}\text { Human Factors: the journal of the human } \\
\text { factors and ergonomics society }\end{array}$ & $\begin{array}{lll}1 & 2 & 3 \\
0 & 0 & 0\end{array}$ & $\begin{array}{ll}4 & 5 \\
0 & 0\end{array}$ & $\begin{array}{lll}1 & 2 & 3 \\
0 & 0 & 0\end{array}$ & $\begin{array}{ll}4 & 5 \\
0 & 0 \\
\end{array}$ & \begin{tabular}{|l} 
Author \\
$\square$ Reviewer
\end{tabular} \\
\hline $\begin{array}{l}\text { I C A O Journal: (International Civil } \\
\text { Aviation Organization) }\end{array}$ & $\begin{array}{lll}1 & 2 & 3 \\
0 & 0 & 0\end{array}$ & $\begin{array}{ll}4 & 5 \\
0 & 0\end{array}$ & $\begin{array}{lll}1 & 2 & 3 \\
0 & 0 & 0\end{array}$ & $\begin{array}{ll}4 & 5 \\
0 & 0\end{array}$ & $\begin{array}{l}\square \text { Author } \\
\square \text { Reviewer }\end{array}$ \\
\hline $\begin{array}{l}\text { IEEE Transactions on Systems, Man, and } \\
\text { Cybernetics }\end{array}$ & $\begin{array}{lll}1 & 2 & 3 \\
0 & 0 & 0\end{array}$ & $\begin{array}{ll}4 & 5 \\
0 & 0 \\
\end{array}$ & $\begin{array}{lll}1 & 2 & 3 \\
0 & 0 & 0\end{array}$ & $\begin{array}{ll}4 & 5 \\
0 & 0 \\
\end{array}$ & $\begin{array}{l}\square \text { Author } \\
\square \text { Reviewer }\end{array}$ \\
\hline $\begin{array}{l}\text { International Journal of Applied Aviation } \\
\text { Studies }\end{array}$ & $\begin{array}{lll}1 & 2 & 3 \\
0 & 0 & 0\end{array}$ & $\begin{array}{ll}4 & 5 \\
0 & 0 \\
\end{array}$ & $\begin{array}{lll}1 & 2 & 3 \\
0 & 0 & 0\end{array}$ & $\begin{array}{ll}4 & 5 \\
0 & 0\end{array}$ & $\begin{array}{l}\square \text { Author } \\
\square \text { Reviewer }\end{array}$ \\
\hline \begin{tabular}{|l} 
International Journal of Aviation \\
Psychology
\end{tabular} & $\begin{array}{lll}1 & 2 & 3 \\
0 & 0 & 0\end{array}$ & $\begin{array}{ll}4 & 5 \\
0 & 0\end{array}$ & $\begin{array}{lll}1 & 2 & 3 \\
0 & 0 & 0\end{array}$ & $\begin{array}{ll}4 & 5 \\
0 & 0\end{array}$ & $\begin{array}{l}\square \text { Author } \\
\square \text { Reviewer }\end{array}$ \\
\hline $\begin{array}{l}\text { International Journal of Human Factors } \\
\text { Modelling and Simulation }\end{array}$ & $\begin{array}{lll}1 & 2 & 3 \\
0 & \bigcirc & 0 \\
\end{array}$ & $\begin{array}{ll}4 & 5 \\
0 & 0 \\
\end{array}$ & $\begin{array}{lll}1 & 2 & 3 \\
0 & 0 & 0\end{array}$ & $\begin{array}{ll}4 & 5 \\
0 & 0 \\
\end{array}$ & $\begin{array}{l}\square \text { Author } \\
\square \text { Reviewer }\end{array}$ \\
\hline $\begin{array}{l}\text { International Journal of Industrial } \\
\text { Engineering: theory, applications and } \\
\text { practice }\end{array}$ & $\begin{array}{lll}1 & 2 & 3 \\
0 & 0 & 0\end{array}$ & $\begin{array}{ll}4 & 5 \\
0 & 0\end{array}$ & $\begin{array}{lll}1 & 2 & 3 \\
0 & 0 & 0\end{array}$ & $\begin{array}{ll}4 & 5 \\
0 & 0\end{array}$ & $\begin{array}{l}\square \text { Author } \\
\square \text { Reviewer }\end{array}$ \\
\hline Journal of Advanced Transportation & $\begin{array}{lll}1 & 2 & 3 \\
0 & 0 & 0\end{array}$ & $\begin{array}{ll}4 & 5 \\
0 & 0 \\
\end{array}$ & $\begin{array}{lll}1 & 2 & 3 \\
0 & 0 & 0 \\
\end{array}$ & $\begin{array}{ll}4 & 5 \\
0 & 0 \\
\end{array}$ & $\begin{array}{l}\square \text { Author } \\
\square \text { Reviewer }\end{array}$ \\
\hline Journal of Air Law and Commerce & $\begin{array}{lll}1 & 2 & 3 \\
0 & 0 & 0 \\
\end{array}$ & $\begin{array}{ll}4 & 5 \\
0 & 0\end{array}$ & $\begin{array}{lll}1 & 2 & 3 \\
0 & 0 & 0\end{array}$ & $\begin{array}{ll}4 & 5 \\
0 & 0\end{array}$ & $\begin{array}{l}\square] \text { Author } \\
\square \text { Reviewer }\end{array}$ \\
\hline Journal of Air Transport Management & $\begin{array}{lll}1 & 2 & 3 \\
0 & 0 & 0\end{array}$ & $\begin{array}{ll}4 & 5 \\
0 & 0\end{array}$ & $\begin{array}{lll}1 & 2 & 3 \\
0 & 0 & 0 \\
\end{array}$ & $\begin{array}{ll}4 & 5 \\
0 & 0 \\
\end{array}$ & $\begin{array}{l}\square \text { Author } \\
\square \text { Reviewer }\end{array}$ \\
\hline Journal of Air Transportation & $\begin{array}{lll}1 & 2 & 3 \\
0 & 0 & 0\end{array}$ & $\begin{array}{ll}4 & 5 \\
0 & 0\end{array}$ & $\begin{array}{lll}1 & 2 & 3 \\
0 & 0 & 0\end{array}$ & $\begin{array}{ll}4 & 5 \\
0 & 0\end{array}$ & $\begin{array}{l}\square \text { Author } \\
\square \text { Reviewer }\end{array}$ \\
\hline
\end{tabular}




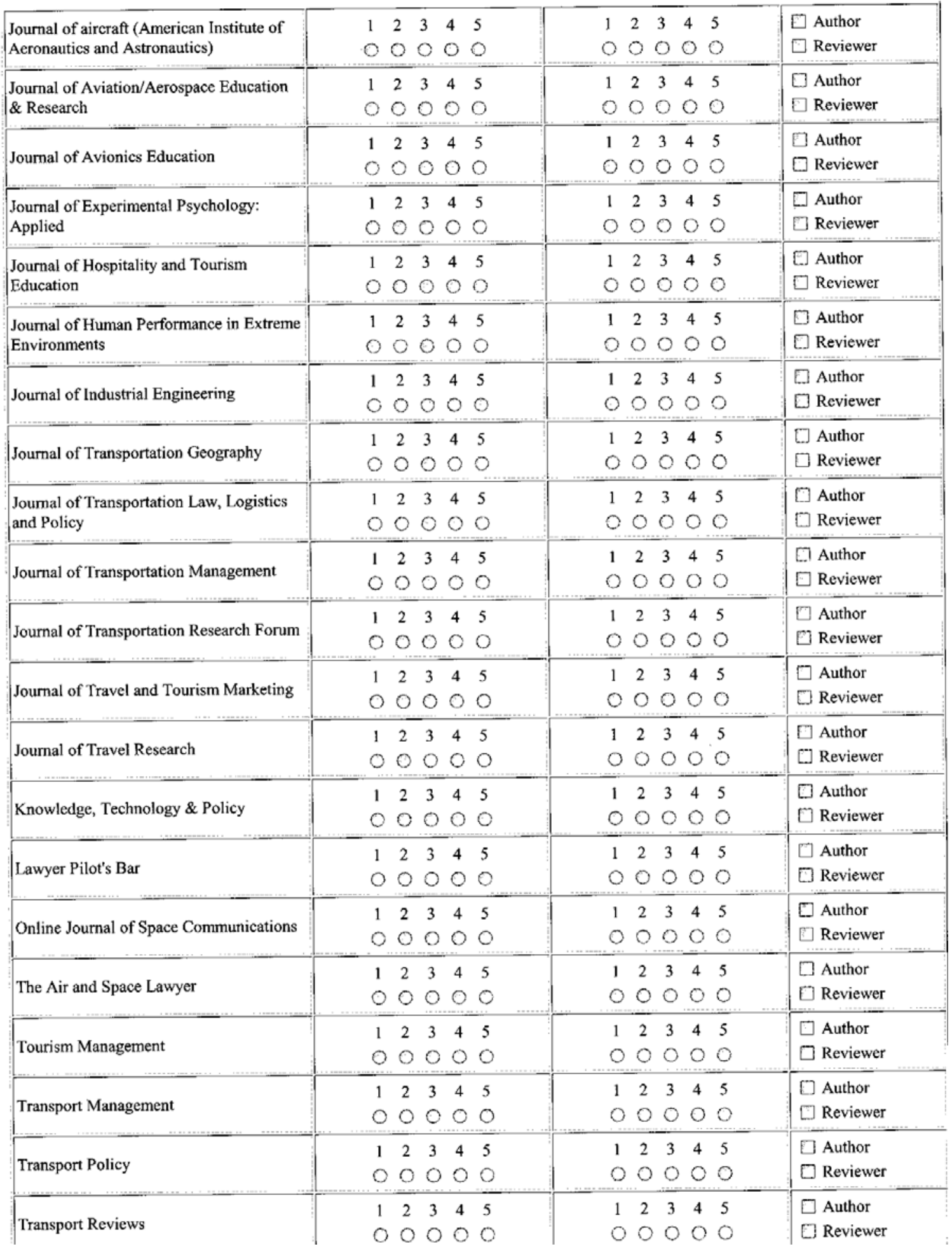




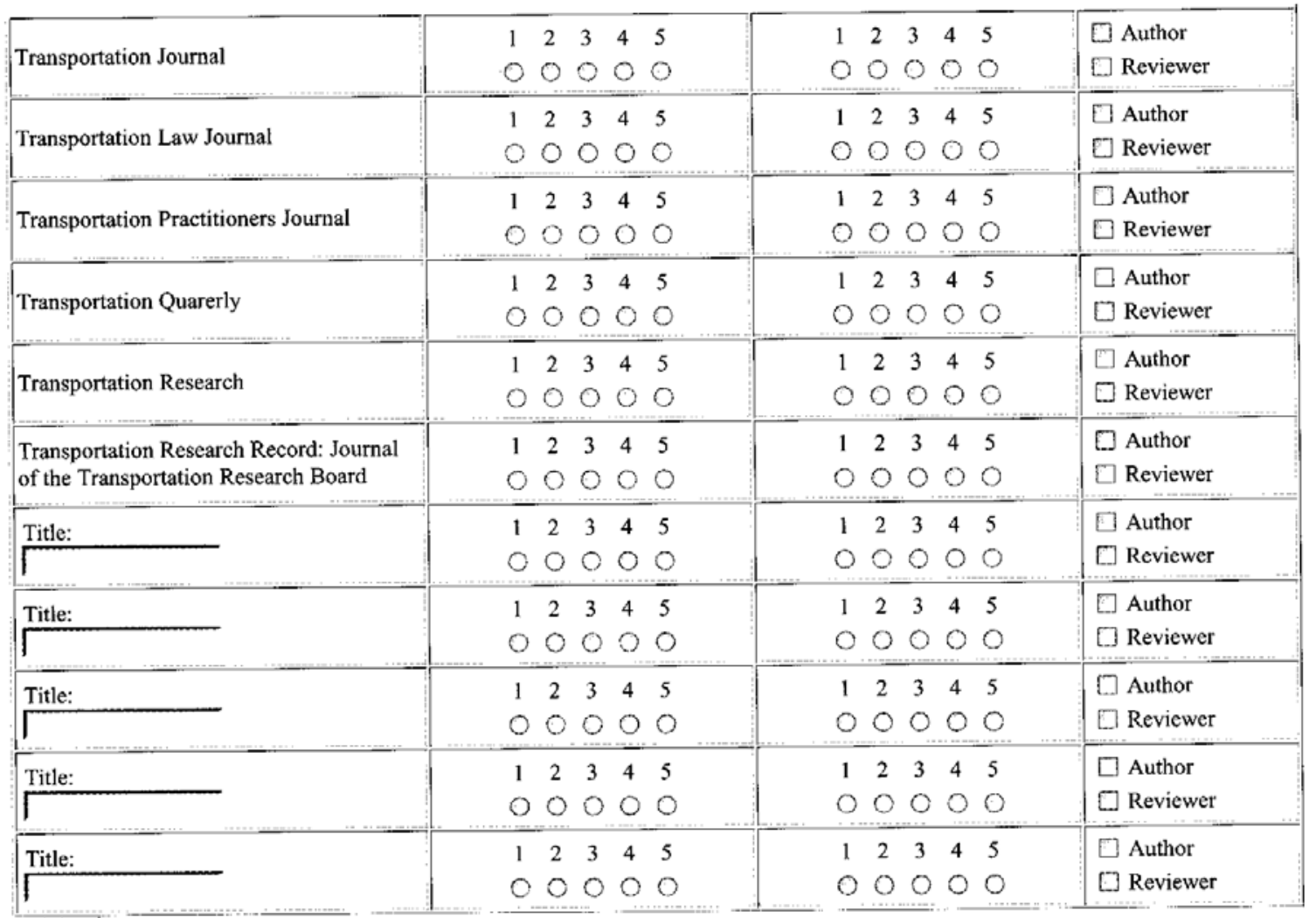


Dear

\section{Appendix C}

The Department of Aviation Management and Logistics at Auburn University invites you to participate in our survey regarding aviation periodicals. Our goal is to identify periodicals that provide exceptional value and utility to academicians. Unlike previous studies that focused primarily on the research quality and prestige of academic journals, our research will investigate a wider set of issues. We hope to gain insight into the value of aviation related periodicals (both academic journals and industry publications) that are used by academicians in their research, outreach, and teaching activities. Thus, your participation is very important to the success of our study.

Survey Instructions:

1. To begin the survey, please point your browsers to http://business.auburn.edu/survey/JournalRankingSurvey.cfm. Answer the survey questions based upon your personal use of aviation-related periodicals for research, outreach, and teaching activities.

2. We have provided a general list of aviation related periodicals (in the drop-down text box) to assist you in filling out the survey. This list is based upon the input of 14 professors teaching in the field of aviation and two previously published studies. However, if you wish to include a journal or publication that is not on the list, you may do so. Please type in these titles where appropriate.

3. All responses to this questionnaire will be strictly confidential.

4. We will be pleased to provide you with a copy of the summarized results if you will furnish your email address or mailing information.

Thank you in advance for your time and effort. If you have any questions, please contact either of us.

Sincerely,

Randy Johnson and Ray Hamilton

Auburn University

Department of Aviation Management and Logistics

334-844-6822 